\title{
Micromorphologic Evidence for Paleosol Development in the Endicott Group, Siksikpuk Formation, Kingak(?) Shale, and Ipewik Formation, Western Brooks Range, Alaska
}

\author{
By Julie A. Dumoulin and Tim White ${ }^{1}$
}

\begin{abstract}
Micromorphologic evidence indicates the presence of paleosols in drill-core samples from four sedimentary units in the Red Dog area, western Brooks Range. Well-developed sepic-plasmic fabrics and siderite spherules occur in claystones of the Upper Devonian through Lower Mississippian(?) Kanayut Conglomerate (Endicott Group), the Pennsylvanian through Permian Siksikpuk Formation (Etivluk Group), the Jurassic through Lower Cretaceous Kingak(?) Shale, and the Lower Cretaceous Ipewik Formation. Although exposure surfaces have been previously recognized in the Endicott Group and Kingak Shale on the basis of outcrop features, our study is the first microscopic analysis of paleosols from these units, and it provides the first evidence of subaerial exposure in the Siksikpuk and Ipewik Formations. Regional stratigraphic relations and geochemical data support our interpretations. Paleosols in the Siksikpuk, Kingak, and Ipewik Formations likely formed in nearshore coastal-plain environments, with pore waters subjected to inundation by the updip migration of slightly brackish ground water, whereas paleosols in the Kanayut Conglomerate probably formed in a more distal setting relative to a marine basin.
\end{abstract}

\section{Introduction}

In this chapter, we present micromorphologic evidence for paleosol formation in four sedimentary units in the western Brooks Range: the Upper Devonian through Lower Mississippian(?) Kanayut Conglomerate of the Endicott Group, the Pennsylvanian through Permian Siksikpuk Formation of the Etivluk Group, strata that most likely represent the Jurassic through Lower Cretaceous Kingak Shale, and the Lower Cretaceous Ipewik Formation. This evidence expands our

\footnotetext{
${ }^{1}$ Current address: Earth and Environmental Systems Institute, Pennsylvania State University, University Park, PA 16802.
}

understanding of the depositional settings in which these units formed. Our samples come from drill cores and outcrops in the vicinity of the Red Dog Mine in northwestern Alaska (fig. 1). Paleozoic and Mesozoic strata in the study area are exposed in a series of discrete structural allochthons that are, in turn, made up of plates, subplates, and duplexes. In this chapter, we use the structural and stratigraphic terminology of Young (2004). All of our samples were obtained from plates in the Endicott Mountains allochthon (figs. 1, 2); in the Red Dog area, these plates consist, in ascending order, of the Wolverine Creek, Red Dog, and Key Creek plates (Dumoulin and others, 2004).

Earlier workers (for example, Nilsen and Moore, 1984) recognized paleosols in the Endicott Group on the basis of outcrop features, and Houseknecht (2001) documented exposure surfaces in the Kingak Shale. However, evidence of subaerial exposure has not previously been described from the Siksikpuk or Ipewik Formation. Although the present work is a reconnaissance study based on a limited number of samples, the distinctive micromorphologic textures of these mostly siderite spherule-bearing samples indicate a paleosol origin. We briefly discuss some of the implications of this interpretation for regional geology and depositional history.

\section{Methodology and Results}

All core and outcrop samples were oriented and polished for transmitted-light microscopy and microprobe analysis. Each sample was carbon coated and analyzed on the JEOL JXA-8900R electron microprobe at the U.S. Geological Survey laboratory in Reston, Va., to accurately assess matrix and carbonate spherule mineralogy (table 1).

Although spherulitic carbonates are not unique to paleosols, the close association of siderite spherules and micromorphologic evidence of pedogenesis in most of our study samples is similar to that observed in many ancient wetland paleosols by earlier researchers (Waage, 1959; Gardner and others, 1988). Notably, most of the siderite spherules we describe display a high Mg content. Mozley (1989) demonstrated that the majoroxide composition of siderite can be an indicator of its environment of formation. Although Curtis and Coleman (1986) 
Table 1. Soil micromorphologic and other petrographic data from thin sections of samples of rocks from the study area.

[See figure 1 for location. All samples have clay matrix. Do., ditto; NA, not applicable]

\begin{tabular}{|c|c|c|c|c|c|c|c|}
\hline Sample & $\begin{array}{l}\text { Age and } \\
\text { formation }\end{array}$ & $\begin{array}{l}\text { Sepic-plasmic } \\
\text { fabric }\end{array}$ & $\begin{array}{l}\text { Fabric } \\
\text { deformed by } \\
\text { spherule }\end{array}$ & $\begin{array}{l}\text { Spherule } \\
\text { mineralogy }\end{array}$ & $\begin{array}{l}\text { Oxidized } \\
\text { spherule } \\
\text { rim }\end{array}$ & Pyrite & $\begin{array}{l}\text { Other } \\
\text { observations }\end{array}$ \\
\hline $\begin{array}{l}1101- \\
600.2\end{array}$ & $\begin{array}{l}\text { Devonian } \\
\text { through Mis- } \\
\text { sissippian(?) } \\
\text { Kanayut Con- } \\
\text { glomerate }\end{array}$ & $\begin{array}{l}\text { Bimasepic } \\
\text { to clinobi- } \\
\text { masepic }\end{array}$ & $?$ & Siderite & no & no & Mottles. \\
\hline $\begin{array}{l}1109- \\
234\end{array}$ & $\begin{array}{l}\text { Pennsylvanian } \\
\text { through Per- } \\
\text { mian Siksik- } \\
\text { puk Formation }\end{array}$ & do. & no & Mg siderite & no & no & $\begin{array}{l}\text { Roots, alveolar } \\
\text { structure } \\
\text { (spherules). }\end{array}$ \\
\hline $\begin{array}{l}1109- \\
242.7\end{array}$ & do. & do. & no & do. & no & no & $\begin{array}{l}\text { Roots and al- } \\
\text { veolar structure } \\
\text { (spherules) with } \\
\text { pedotubules. }\end{array}$ \\
\hline 99AD6I & do & NA & $\begin{array}{r}\text { Laminations } \\
\text { deformed }\end{array}$ & Rhodochrosite & yes & yes & NA \\
\hline $\begin{array}{l}1110- \\
1937\end{array}$ & $\begin{array}{l}\text { Jurassic(?) } \\
\text { Kingak(?) } \\
\text { Shale }\end{array}$ & $\begin{array}{c}\text { Bimasepic to } \\
\text { lattisepic }\end{array}$ & yes & $\mathrm{Mg}$ siderite & yes & no & $\begin{array}{l}\text { Roots and al- } \\
\text { veolar structure } \\
\text { (spherules) with } \\
\text { pedotubules and } \\
\text { dolomite rhombs. }\end{array}$ \\
\hline $\begin{array}{l}781- \\
1459\end{array}$ & $\begin{array}{l}\text { Cretaceous } \\
\text { Ipewik Forma- } \\
\text { tion }\end{array}$ & $\begin{array}{l}\text { Insepic to } \\
\text { mosepic }\end{array}$ & yes & do. & no & yes (minor) & Pedoturbation(?). \\
\hline
\end{tabular}

interpreted elevated $\mathrm{Mg}$ content in siderite as due to late-stage diagenetic processes, Mozley and Carothers (1992) determined that impure, Mg-rich siderite is typical of early diagenetic marine siderite. More recently, White and others (2005) applied these concepts to document variations in the updip migration of brackish pore waters in Paleozoic and Mesozoic coastal-plain paleosols; the variations were tied to changes in relative sea level. Following these approaches, we consider the presence of magnesian siderite in our samples as indicative of marine influence on paleosols that likely formed in nearshore coastal-plain settings. The presence in some of the samples of syngenetic pyrite, most prevalent in sulfate-rich marine to brackish environments of formation (for example, Davison, 1988), strengthens this interpretation for those horizons.

A soil-micromorphologic analysis of each thin section was made, with particular emphasis on the presence or absence of sepic-plasmic fabrics, which are highly birefringent streaks in the soil matrix that are formed by stresses in clayey soils during wetting and drying (FitzPatrick, 1993). The development of sepicplasmic fabrics from simple patches to well-oriented networks is partly determined by the intensity of, or time available for, soil formation (Collins and Larney, 1983). Here, we describe insepic (small isolated patches of streaks), mosepic (partly adjoining patches), bimasepic (network with two preferred directions), clinobimasepic (as bimasepic but at low angle), and lattisepic (as bimasepic but at right angle) fabrics (Retallack, 1997). Other soil microfabrics were observed in our samples, most notably root structures and alveolar fabrics, which are thin domains of sparry calcite associated with roots (Retallack, 1997). These observations are summarized in table 1.

\section{Endicott Group}

The Endicott Group is a chiefly siliciclastic succession deposited mainly in a shallow-marine to nonmarine setting. The succession comprises, from bottom to top, the Hunt Fork Shale, Noatak Sandstone, Kanayut Conglomerate, and Kayak Shale (fig. 2). Our sample comes from an interval of Kanayut Conglomerate logged in Teck-Cominco diamond-drill hole (DDH) 1101 in

${ }^{2}$ Unit thicknesses in drill cores given here have not been corrected for dip and are thus somewhat greater than true thicknesses. Bedding dips recorded on drill logs in the cores sampled are generally $20-40^{\circ}$, and so true thicknesses are $\sim 6-23$ percent less than measured thicknesses. 
the Noatak quadrangle (fig. 1). DDH 1101 penetrated $\sim 135 \mathrm{~m}$ of Kanayut Conglomerate overlain by $\sim 140 \mathrm{~m}$ of shale, limestone, and sandstone of the Kayak Shale. ${ }^{2}$ These strata are all part of the Red Dog plate of the Endicott Mountains allochthon (Young, 2004). The Kanayut Conglomerate here is a fine- to mediumgrained, quartz-rich sandstone with subordinate pebble conglomerate and red and green mudstone. Sample 1101-600.2 was obtained $\sim 4 \mathrm{~m}$ above the base of a 22-m-thick interval of mudstone at the top of the Kanayut. The mudstone is dominantly greenish gray, but the sample was taken near the base of a 7.5-m-thick zone that is bright maroon and contains disseminated rounded to irregular white fragments, $\leq 2 \mathrm{~cm}$ in diameter.

In thin section, sample 1101-600.2 is a deep-reddishbrown claystone with minor disseminated angular to subangular, monocrystalline quartz silt, and irregular sand-size grains of carbonate that are likely siderite. The clay matrix displays well-developed bimasepic to clinobimasepic fabrics (fig. $3 \mathrm{~A}$ ) formed during pedogenesis.

\section{Implications}

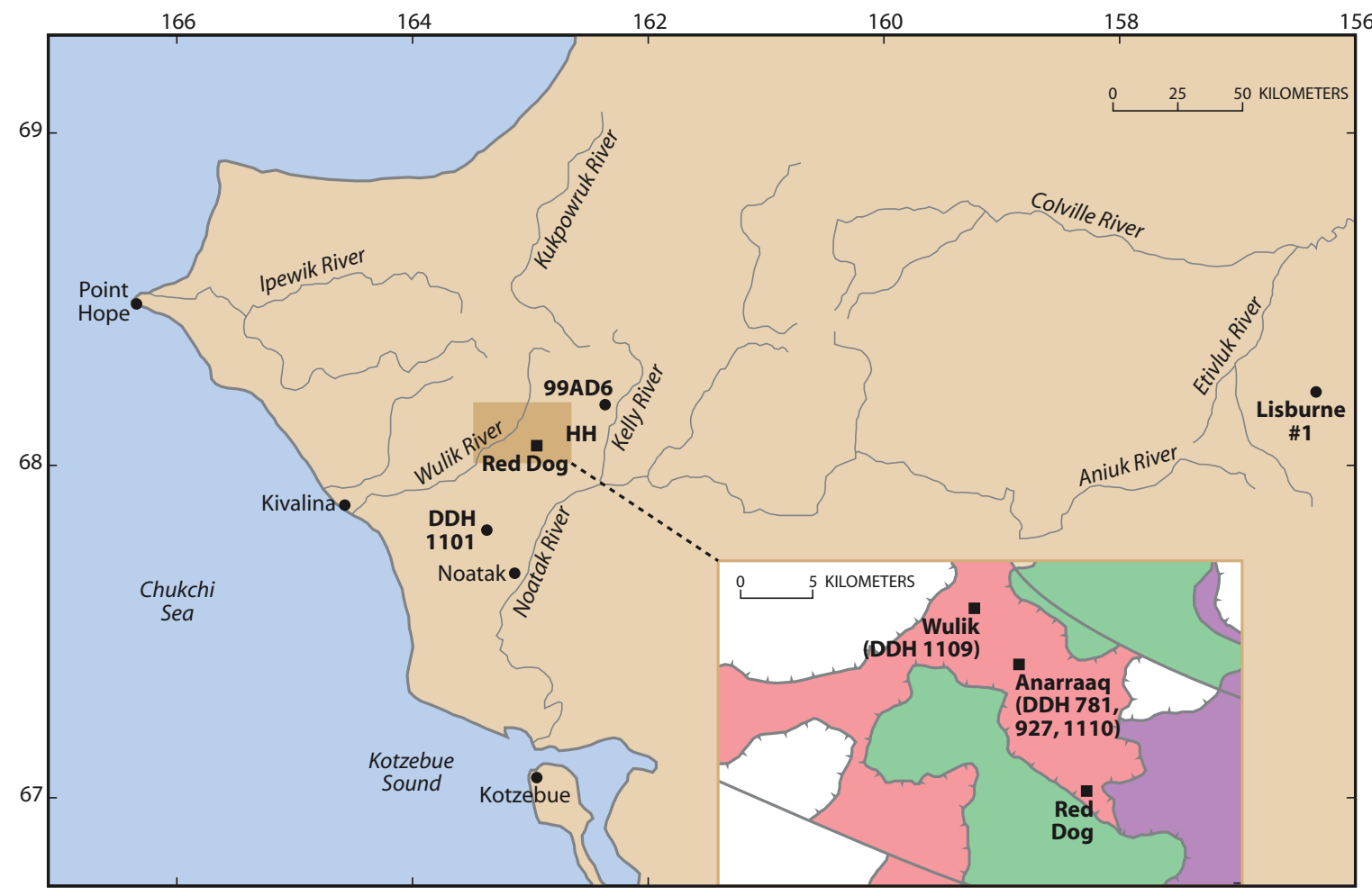

\section{EXPLANATION}

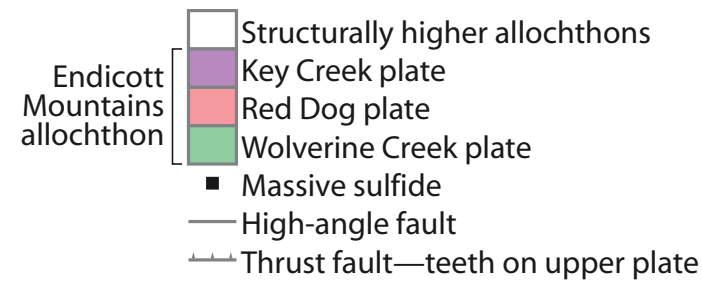

Figure 1. Northwestern Alaska, showing locations of study area and massive sulfide deposits, diamond-drill holes (DDHs), and outcrop samples discussed in text; inset shows plates of the Endicott Mountains allochthon in area of the Red Dog Mine (De Vera and others, 2004). HH, Husky Hills. 
cott Group beneath the North Slope, which he interpreted as having been deposited in an emergent continental setting.

Geochemical evidence also supports the existence of emergent conditions during deposition of the Kanayut Conglomerate in the western Brooks Range (fig. 1). In weathering environments, such chemical elements as $\mathrm{Ca}$ and $\mathrm{Na}$ are preferentially leached, while such elements as $\mathrm{Al}$ are generally conserved, providing the basis for the "chemical index of alteration" (CIA) of Nesbitt and Young (1982). Extensive weathering (either in the source terrane or after deposition) typically yields high CIA values of $>80$. Gray and maroon shales of the Kanayut Conglomerate in the western Brooks Range, the rock type from which our sample was obtained, have CIA values of 80.7 to 84.6 (Slack and others, 2004), the highest of any Paleozoic unit in the study area (fig. 1).

\section{Siksikpuk Formation}

The Pennsylvanian through Jurassic Etivluk Group (Mull and others, 1982), which includes the Siksikpuk and overlying Otuk Formations (fig. 2), is thought to have formed mainly in a marine-shelf setting (Bodnar, 1984; Siok, 1985; Young, 2004). In the western Brooks Range (figs. 1, 2), the Siksikpuk Formation of the Endicott Mountains allochthon (Red Dog and Key Creek plates) is $\sim 70$ to $100 \mathrm{~m}$ thick and encompasses four informal subunits (Young, 2004). (1) The lower subunit (20-40 m thick) consists of gray and black chert, lesser siliceous shale, and local ferroan dolostone; shale is most abundant in the upper part of this subunit. (2) The middle subunit (23-46 m thick) consists of laminated to thin-bedded, greenish-gray and maroon aluminous shale and lesser chert; chert occurs mostly in the upper part of this subunit. (3) The upper subunit (9-46 m thick) consists mainly of greenish-gray and maroon chert. (4) A transitional subunit ( $\geq 8 \mathrm{~m}$ thick) at the top of the Siksikpuk contains gray and lesser maroon shale, subordinate chert, and minor chert-rich

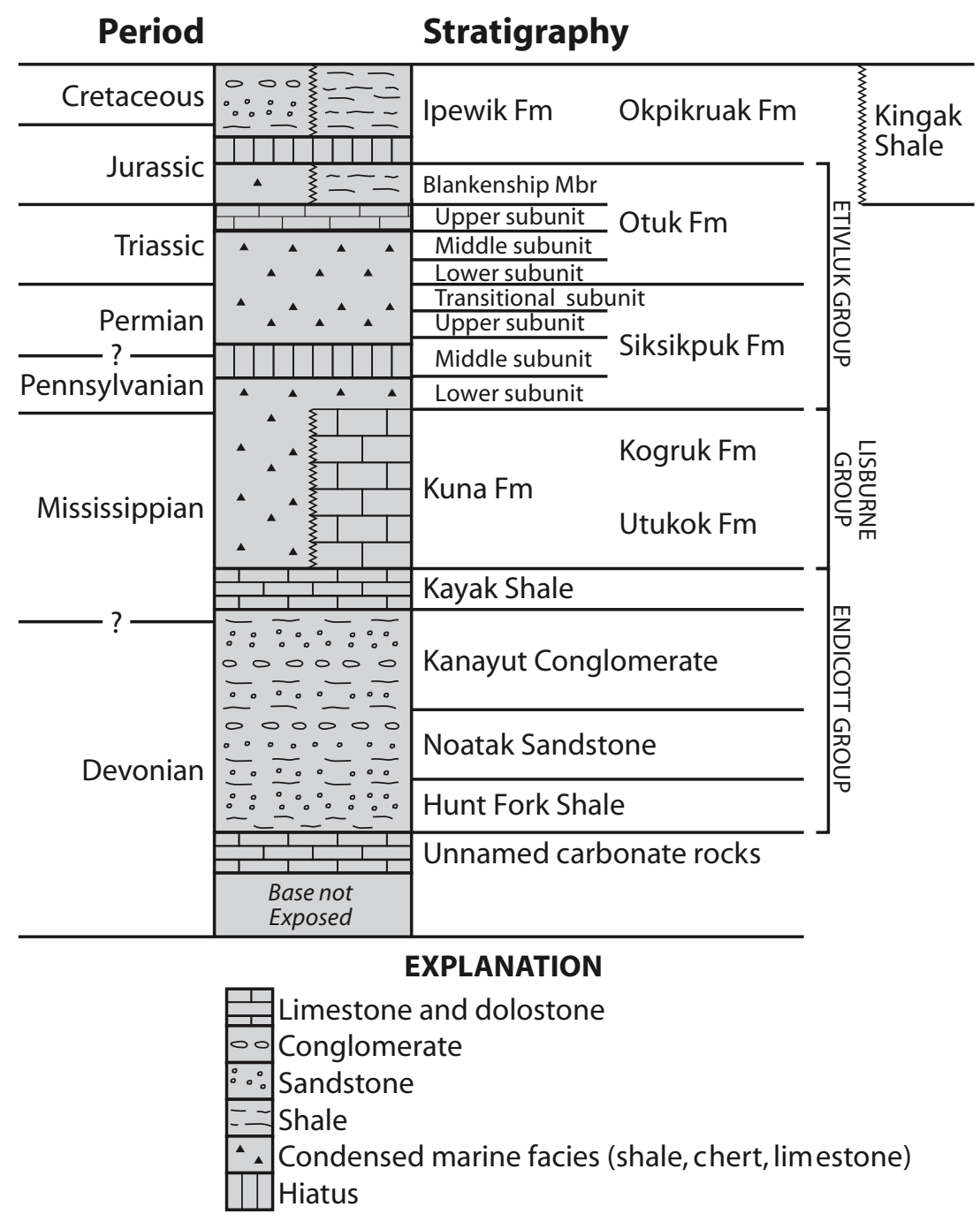

Figure 2. Generalized stratigraphic column for the Endicott Mountains allochthon in the western Brooks Range (fig. 1), showing principal Paleozoic and Mesozoic units. Modified from Young (2004). Thicknesses are schematic. 
siltstone; these rocks conformably underlie and locally intertongue with the basal part of the Otuk Formation.

We analyzed three samples from the lower and middle subunits of the Siksikpuk Formation. Core samples 1109-234 and 1109-242.7 (table 1) are from a tectonically thickened interval in the lower subunit in DDH 1109, which penetrated the Wulik deposit in the Red Dog plate northwest of the Red Dog Mine (fig. 1). The interval is $>120 \mathrm{~m}$ thick and is bounded and cut by numerous faults; it underlies the middle unit of the Siksikpuk Formation and overlies the upper part of the Kuna Formation. At least three imbricated repeats of partial sections of the lower member were recognized in the drill-hole log; each section is $\sim 40$ to $50 \mathrm{~m}$ thick and consists mainly of medium-light- to medium-dark-gray noncalcareous shale. Near the middle of the highest imbricate, several 1-cm-thick horizons contain abundant pinkishyellow, rounded to rhombic carbonate spherules, mostly 100 to $300 \mu \mathrm{m}$ in diameter; some spherules have coalesced into clumps, 600 to $800 \mu \mathrm{m}$ across.

The third sample (99AD6I, table 1) of the Siksikpuk Formation was obtained from an outcrop of Key Creek strata, $\sim 18 \mathrm{~km}$ northeast of the Red Dog Mine (fig. 1). The upper part of the Kuna Formation and the lower part of the overlying Siksikpuk Formation are well exposed here and have been dated as late Late Mississippian to early Middle Pennsylvanian (Chesterian to Morrowan), on the basis of radiolarians and conodonts (Dumoulin and others, in press). Above the chertrich part of the section, green and red shales of the middle subunit of the Siksikpuk Formation contain millimeter-scale rhodochrosite spherules with spherulitic extinction (fig. $3 B$ ).

\section{Implications}

Unequivocal evidence for paleosol formation in the Siksikpuk Formation is visible in the form of carbonized rootlets in thin sections of our two core samples (figs. $3 C, 3 D$ ), which display bimasepic to clinobimasepic matrix fabrics also indicative of pedogenesis. The matrix fabrics are undeformed by the sideritic alveolar structures (spherules), which engulf roots, indicating that the siderite formed during pedogenesis. The magnesian chemistry of the spherules indicates that brackish waters likely influenced the horizon during pedogenesis.

As noted above, the Siksikpuk Formation is generally considered to have formed in a marine-shelf setting, and the sedimentologic data described here are the first evidence that its formation was interrupted by one or more periods of subaerial exposure. Regional stratigraphic relations and paleontologic and geochemical data provide ample evidence for erosive intervals and (or) periods of nondeposition, which circumstantially supports the presence of paleosols in the unit. For example, in the central Brooks Range, the basal part of the Siksikpuk Formation in the Endicott Mountains allochthon is of Early Permian age and disconformably overlies Lisburne Group strata that are no younger than early Middle Pennsylvanian (Morrowan), thus indicating a hiatus of at least 15 m.y. (Menning and others, 2000). Erosional relief of at least $0.5 \mathrm{~m}$ has been noted along this surface (Adams and others, 1997). An unconformity of similar duration but with as much as $20 \mathrm{~m}$ of relief separates the Lisburne Group from the overlying Sadlerochit Group in the northeastern Brooks Range (Crowder, 1990). In the western Brooks Range, faunal data suggest that a similar hiatus occurs within the Siksikpuk Formation. In the Red Dog area (fig. 1), the Lisburne GroupSiksikpuk Formation contact appears to be conformable, and radiolarians in the lower subunit of the Siksikpuk Formation are no younger than Morrowan (Dumoulin and others, 2004, in press). Radiolarians in the upper part of the middle subunit, however, are Middle Permian, and no fossils diagnostic of late Middle through Late Pennsylvanian or earliest Permian (Wolfcampian) age have been observed in the intervening shale-rich section (Dumoulin and others, in press). A similar time gap in radiolarian faunas from the lower part of the Etivluk Group also occurs in the west-central Brooks Range (Dover and others, 2004).

Geochemical data support the suggestion that deposition of the Siksikpuk Formation in the Red Dog area (fig. 1) was disrupted before and (or) during accumulation of the shale-rich middle part of the formation. The transition from the lower to middle subunit of the Siksikpuk Formation is marked by a major shift in shale composition that appears to reflect changes in provenance and basin architecture (Young, 2004). Shale of the lower subunit is siliceous and alumina poor, whereas that of the middle subunit is much less siliceous and more aluminous (Young, 2004). CIA values from greenish-gray and maroon shales of the Siksikpuk Formation in the western Brooks Range are generally lower than those from shales of the Kanayut Conglomerate, although several CIA values from the Siksikpuk are $>80$ (J.F. Slack, written commun., 2005). Such values are consistent with periods of exposure and weathering during the evolution of the Siksikpuk Formation.

The rhodochrosite spherule-bearing outcrop sample (fig. $3 B$ ) provides no evidence for pedogenesis. Nonetheless, spherule-bearing horizons with varying mineralogy have been shown to occupy the same stratigraphic position over large areas (Miall, 1974). In addition, spherule-bearing horizons including paleosols commonly occur at or near unconformities (Mozley and Carothers, 1992; White and others, 2005). For example, Middle Cretaceous siderite spherule-bearing paleosols are widespread throughout North America (White and others, 2000) and globally (Sigleo and Reinhart, 1988) and are coeval with rhodochrosite-bearing deposits in the Canadian Arctic (Miall, 1974) and on the north coast of Australia (Pracejus and Bolton, 1992). Therefore, given the imprecision of correlation between our core and outcrop samples, we surmise that the paleosols in the Siksikpuk Formation may be approximately coeval with the rhodochrosite spherule-bearing unit. The presence of pyrite in the outcrop sample matrix, which in places is engulfed by spherules, demonstrates that rhodochrosite precipitation occurred within sediment earlier subjected to sulfate reduction, that is, most likely in a brackish or marine setting. Considering this interpretation, the rhodo- 

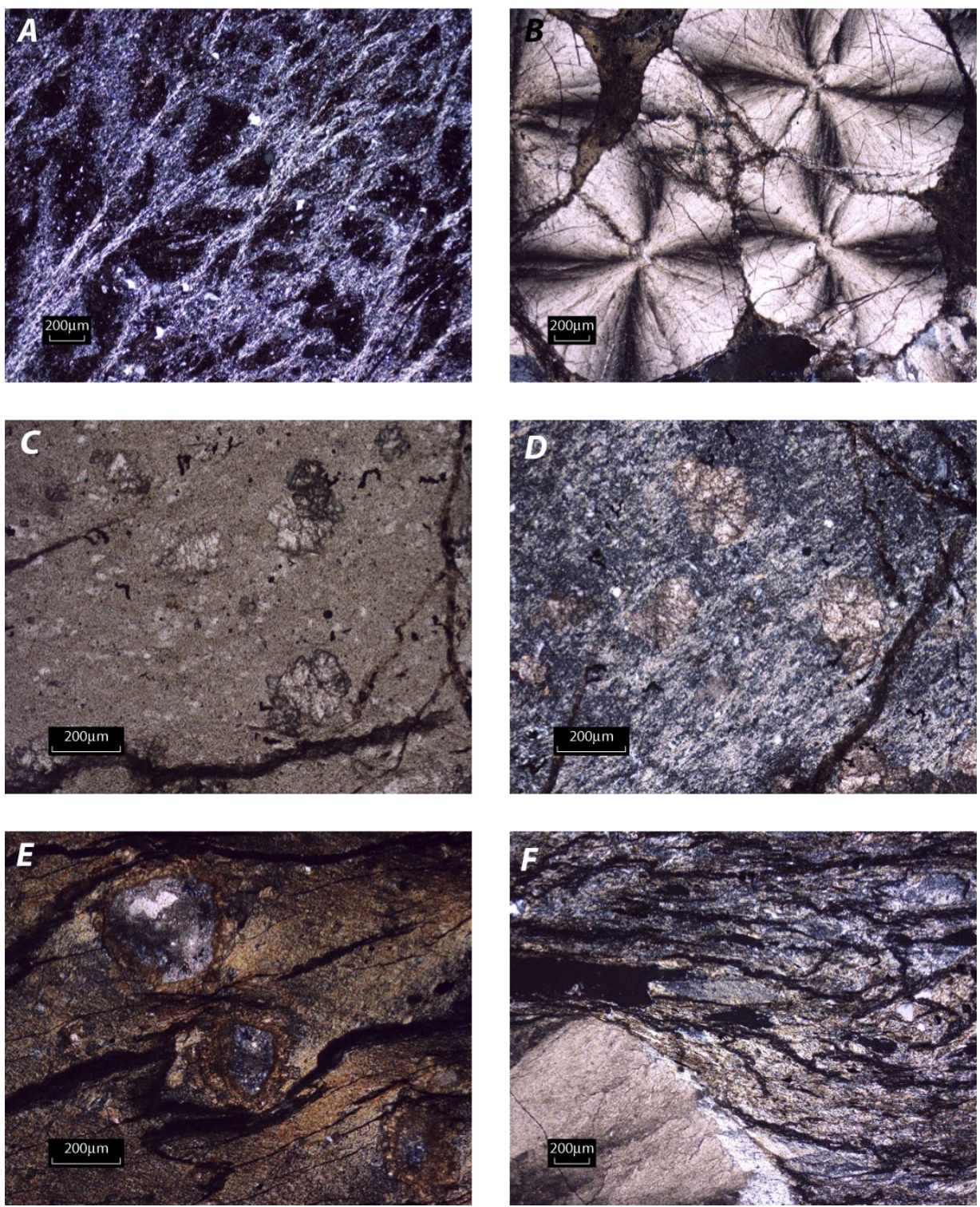

Figure 3. Thin-section photomicrographs, mostly of various characteristic fabrics indicative of pedogenesis in samples studied (table 1). A, Sample 1101-600.2. Bimasepic to clinobimasepic fabric viewed under crossed nicols in Devonian through Mississippian(?) Kanayut Conglomerate provides evidence for pedogenesis; fabric is manifest in thin section as two sets of highly birefringent streaks, some of which intersect at low angles. Note dark mottles that in places appear to engulf fabric. $B$, Sample 99AD6I. Rhodochrosite spherules in Siksikpuk Formation, showing pseudouniaxial crosses typical of carbonate spherules viewed under crossed nicols. Note pyrite visible as small black grains embedded in brown claystone matrix. C, Sample 1109-242.7. Lightbrown to tan silty claystone paleosol from Siksikpuk Formation viewed in plane-polarized light. Note conspicuous bifurcating root on right side. Large light-colored clots are magnesian sideritic pseudospherules. $D$, Same field of view as in figure $3 C$ but slightly rotated under crossed nicols. Note that root visible in figure $3 C$ is visible in upper right corner. Bimasepic to clinobimasepic fabric is visible among spherules, though not as pronounced as in figure 3A. E, Sample 1110-1937. Magnesian siderite spherules in a silty claystone paleosol from Kingak(?) Shale viewed under crossed nicols. Note patchy distribution of bimasepic to lattisepic fabric ("scotch plaid"), presence of small domains of pyrite, and prevalence of small dolomite rhombs throughout matrix. F, Sample 781-1459. Large magnesian siderite spherule (lower left corner) in Ipewik Formation. Note patchy distribution of insepic to mosepic fabric. 
chrosite spherules are most easily explained as having formed in a basinward position relative to the paleosols.

\section{Kingak(?) Shale}

Another sample considered in this study is from a section of black noncalcareous mudstone, at least $30 \mathrm{~m}$ thick, that overlies the limy subunit of the Otuk Formation in two adjacent drill holes near the Anarraaq deposit (fig. 1). The mudstone occurs in DDH 1110 and 927, which are located $\sim 1.5$ and $2.7 \mathrm{~km}$ west of Anarraaq, respectively. The upper contact of the mudstone in both drill holes is a fault. These rocks, which compose part of the Wolverine Creek plate of the Endicott Mountains allochthon (figs. 1,2) were called the Kingak Shale by Young (2004). The Kingak Shale (Jurassic through Lower Cretaceous), which consists of dark shale and lesser siltstone and ranges from 17 to $>1,000 \mathrm{~m}$ in thickness (Magoon and Bird, 1988), crops out in the northeastern Brooks Range, is widely present in the subsurface beneath the North Slope, and has been recognized locally in the Wolverine Creek plate in the western Brooks Range (Young, 2004). Its lower part is correlative with the Blankenship Member of the Otuk Formation, a distinctive organic-rich shale, less than $7 \mathrm{~m}$ thick, of Early and Middle Jurassic age that occurs discontinuously through the western and central Brooks Range (Mull and others, 1982). The Blankenship Member, which occurs locally in the Key Creek and Red Dog plates of the Endicott Mountains allochthon (Young, 2004), is distinguished from the age-equivalent lower part of the Kingak Shale by the presence of fissile oil shale and chert, which are absent in the Kingak (Mull and others, 1982). The lithology and structural position of the mudstone section in DDHs 927 and 1110 thus suggest that these rocks are part of the Kingak Shale. A similar section of dark shale, also $30 \mathrm{~m}$ thick and of possible Early through Middle Jurassic age, overlies the limy subunit of the Otuk Formation in the Ivotuk plate of the Endicott Mountains allochthon in the Lisburne 1 well, $300 \mathrm{~km}$ east of Red Dog (fig. 1).

Kingak(?) Shale in the Anarraaq drill holes (fig. 1) is grayish and brownish black to black and relatively organic rich. Total organic-carbon (TOC) contents of 1.4 to 3.6 weight percent were measured in nine representative samples from throughout the section (R. Burruss, written commun., 2005). These TOC contents are similar to those in samples of Kingak Shale from North Slope wells and the northeastern Brooks Range, which range from 0.5 to 3 weight percent (Magoon and others, 1987; Magoon and Bird, 1988), but are less than those typical of the Blankenship Member, which average 6.8 weight percent in the central Brooks Range (Bodnar, 1984). Subtle, millimeter-thick brown and blue laminae, in some areas partly disrupted by bioturbation and soft-sediment folding, occur locally in the Kingak(?) Shale in the Anarraaq area. Lenses and irregular blebs of pyrite, as much as $1 \mathrm{~cm}$ in diameter, are scattered throughout the section; some of these may be pyritized burrows. Most samples of Kingak(?) Shale from both drill holes contain traces of quartz silt, and a few samples contain minor silt- to sand-size carbonate rhombs.
Stratigraphic relations suggest a latest Triassic or younger age for the Kingak(?) Shale in the Anarraaq area (fig. 1). Its basal contact with the limy subunit of the Otuk Formation appears to be conformable, and the limy subunit is well dated as Late Triassic (middle through late Norian) both regionally (Bodnar, 1984; Young, 2004) and in the Red Dog area (Dumoulin and others, in press). Poorly preserved radiolarian ghosts(?), as well as rare calcareous and (or) phosphatic shell fragments (some of which may be pelecypods), occur in the lower part of the Kingak(?) but do not constrain its age. Nine samples of Kingak(?) Shale were analyzed for pollen, but only relict spores of indeterminate age were recovered (D. Goodman, written commun., 2003).

Sample 1110-1937 (table 1) was obtained from a 3-cmthick layer of black mudstone containing abundant rounded magnesian siderite spherules 100 to $500 \mu \mathrm{m}$ in diameter that have an oxidized rim, small dolomite rhombs $\sim 20 \mu \mathrm{m}$ in diameter, and pyrite grains $\sim 10 \mu \mathrm{m}$ in diameter. The mudstone matrix is characterized by bimasepic to lattisepic fabric and root structures indicative of pedogenesis (fig. $3 E$ ). The root structures appear to have been deformed by spherule growth.

\section{Implications}

The pedogenic paragenesis of the sample studied can be summarized as follows: (1) dolomite precipitation, (2) magnesian siderite spherule formation in an environment subjected to brackish or marine influence, (3) formation of soil fabric in an environment subjected to alternating wet and dry conditions, and (4) oxidation of the outer spherule rim. The paucity of early diagenetic pyrite in the sample suggests that brackishpore-water evolution had advanced through complete sulfate reduction; this setting is most simply envisioned as having occurred in the most distal (landward or updip) reaches of brackish-ground-water inundation from a nearby sea.

One interpretation of this sequence of events is that the dolomite precipitated from evolved marine pore waters, because dolomite is considered a normal early diagenetic carbonate in marine mudrocks in which sulfate reduction has advanced to completion (Curtis and Coleman, 1986). Because of the high molar $\mathrm{Mg}^{2+} / \mathrm{Ca}^{2+}$ ratio of seawater, siderite that precipitated from the remaining pore waters would be expected to have a high $\mathrm{Mg}$ content (Curtis and Coleman, 1986). Thus, the sequence of events may represent an overall withdrawal of marine influence from a saturated coastal-wetland paleosol. Through this process, the soil was progressively subjected to increasing drainage and oxidative processes, as relative regression progressed and base level fell. Exposure surfaces that may correlate with the observed paleosol horizon in the Kingak(?) Shale in the Anarraaq area (fig. 1) have been recognized in Kingak Shale penetrated by wells on the North Slope (Houseknecht, 2001; Houseknecht and Bird, 2004), several hundred kilometers northeast of the Red Dog area. These surfaces have a "reddish stain $* * *$ evidence of erosion of lithified or semilithified sediment, and fabrics that suggest pedogenic processes" (Houseknecht, 2001, p. 79). Such surfaces occur in Lower Jurassic strata of the lower part 
of the Kingak Shale (depositional-sequence set K1 of Houseknecht, 2001), which are truncated by an unconformity that spans at least $20 \mathrm{~m} . \mathrm{y}$. and encompasses most of the Middle and Late Jurassic (Aalenian through Oxfordian). Paleontologic data indicate that an equivalent hiatus occurs in coeval rocks throughout the western and central Brooks Range (Mull and others; 1982; Dover and others, 2004).

\section{Ipewik Formation}

Variegated mudstone of the Lower Cretaceous (Valanginian) Ipewik Formation (Young, 2004), part of the Red Dog plate of the Endicott Mountains allochthon, forms a thin ( $\sim 3 \mathrm{~m}$ thick) fault-bounded section in DDH 781, $1.2 \mathrm{~km}$ northeast of the Anarraaq deposit (figs. 1, 2). The section, which is overlain by melange and underlain by mudstone of the Okpikruak Formation, consists of greenish-gray and very dark red soft shale. The lower $30 \mathrm{~cm}$ of the section is red, with grayish-green and light-olive-gray mottles and creamcolored spherules, 2 to $3 \mathrm{~mm}$ in diameter. Sample 781-1459 (table 1) from this mottled interval is mudstone with minor disseminated, fine to very coarse sand grains that consist mostly of quartz but include one granitic clast and several carbonate concretions. Insepic to mosepic fabrics are visible in thin section, along with deformed and disrupted horizons suggestive of pedoturbation, magnesian sideritic spherules, and pyrite (fig. $3 F$ ).

\section{Implications}

The Ipewik Formation in the Red Dog area (fig. 1) has received little detailed study. Young (2004) interpreted it as a marine deposit formed during the waning stages of northerly derived sedimentation, and proposed a Valanginian age on the basis of regional correlations. Valanginian strata in the subsurface below the North Slope are part of the Kingak Shale and make up depositional-sequence set K3 of Houseknecht (2001) and Houseknecht and Bird (2004).

The magnesian siderite and pyrite in our sample (781-1459, table 1) of the Ipewik Formation could represent a marine diagenetic sequence in which pyrite precipitation led to (1) the removal of dissolved sulfate from pore waters, a prerequisite to siderite formation; and (2) a decrease in pore-water $\mathrm{Fe}^{2+} / \mathrm{Mg}^{2+}$ ratio to such an extent that subsequent siderite was Mg rich (Mozley and Carothers, 1992). Insepic to mosepic fabrics, however, indicate that pedogenesis led to the formation of immature soils. Significantly, Mozley and Carothers recognized that siderite is a major authigenic mineral in the coeval(?) Neocomian Upper Member of the Kuparuk Formation beneath the North Slope (Mozley and Carothers, 1992), where sedimentary deposition is posited to have occurred above an unconformity in marine-shelf deposits (Masterson and Paris, 1987). Our paleosol interpretation is supported by the presence of exposure surfaces in coeval rocks of depositional-sequence K3 penetrated in North Slope wells, similar to those observed in depositional-sequence set K1 discussed earlier (Houseknecht, 2001).

\section{Conclusions}

Our study provides micromorphologic evidence of paleosol formation in the Kanayut Conglomerate (Devonian through Mississippian?), Siksikpuk Formation (Pennsylvanian through Permian), Kingak(?) Shale (Jurassic through Cretaceous), and Ipewik Formation (Cretaceous) in the Red Dog area of the western Brooks Range (fig. 1). Claystone samples from all four units contain sepic-plasmic fabrics, as well as siderite spherules; several samples also contain root structures and alveolar fabrics. Regional correlations and geochemical data support an interpretation of emergent conditions during deposition of the Kanayut Conglomerate and Siksikpuk Formation. Paleosol horizons in the Kingak(?) Shale and Ipewik Formation may correlate with the exposure surfaces recognized by Houseknecht (2001) in Kingak strata beneath the North Slope.

\section{Acknowledgments}

This study was part of a cooperative research project between Teck Cominco American Inc. and the U.S. Geological Survey. We thank all the Teck Cominco staff involved, especially Jeff Clark, Scott Jennings, Adrian King, and Lorne Young, and our U.S. Geological Survey colleagues, particularly Harvey Belkin, Robert Burruss, Karen Kelley, and John Slack, for helpful discussions and critical logistic support. Thanks also to Karen Kelley and P. Lee Phillips (University of North Carolina, Pembroke) for helpful and timely reviews of the manuscript, and to Phil Kolb (Pennsylvania State University) for his graphics expertise.

\section{References Cited}

Adams, K.E., Mull, C.G., and Crowder, R.K., 1997, Permian deposition in the north central Brooks Range, Alaska; constraints for tectonic reconstructions: Journal of Geophysical Research, v. 12, no. B9, p. 20727-20748.

Bodnar, D.A., 1984, Stratigraphy, age, depositional environments, and hydrocarbon source rock evaluation of the Otuk Formation, north-central Brooks Range, Alaska: Fairbanks, University of Alaska, M.S. thesis, 231 p.

Collins, J.F., and Larney, F.J., 1983, Micromorphological changes with advancing pedogenesis in some Irish alluvial soils, in Bullock, Peter, and Murphy, C.P., eds., Techniques and applications, v. 1 of Soil micromorphology: Berkham- 
sted, U.K., A.B. Academic, p. 297-301.

Crowder, R.K., 1990, Permian and Triassic sedimentation in the northeastern Brooks Range, Alaska; deposition of the Sadlerochit Group: American Association of Petroleum Geologists Bulletin, v. 74, no. 9, p. 1351-1370.

Curtis, C.D., and Coleman, M.L., 1986, Controls on the precipitation of early diagenetic calcite, dolomite and siderite concretions in complex depositional sequences, in Gautier, D.L., ed., Roles of organic matter in sediment diagenesis: Society of Economic Paleontologists and Mineralogists Special Publication 38, p. 23-33.

Davison, William, 1988, Interactions of iron, carbon and sulfur in marine and lacustrine sediments, in Fleet, A.J., Kelts, Kerry, and Talbot, M.R., eds., Lacustrine petroleum source rocks: Geological Society of London Special Publication 40, p. 131-137.

De Vera, Jose, McClay, K.R., and King, A.R., 2004, Structure of the Red Dog district, western Brooks Range, Alaska: Economic Geology, v. 99, no. 7, p. 1415-1434.

Dover, J.H., Tailleur, I.L., and Dumoulin, J.A., 2004, Geologic and fossil locality maps of the west-central part of the Howard Pass quadrangle and part of the adjacent Misheguk Mountain quadrangle, western Brooks Range, Alaska: U.S. Geological Survey Miscellaneous Field Studies Map MF-2413, 25 p., scale 1:100,000, 2 sheets.

Dumoulin, J.A., Harris, A.G., Blome, C.D., and Young, L.E., 2004, Depositional settings, correlation, and age of Carboniferous rocks in the western Brooks Range, Alaska: Economic Geology, v. 99, no. 7, p. 1355-1384.

Dumoulin, J.A., Harris, A.G., Blome, C.D., and Young, L.E., in press, Conodont and radiolarian data from the De Long Mountains quadrangle and adjacent areas: U.S. Geological Survey Open-File Report.

FitzPatrick, E.A., 1993, Soil microscopy and micromorphology: New York, John Wiley and Sons, 304 p.

Gardner, T.W., Williams, E.G., and Holbrook, P.W., 1988, Pedogenesis of some Pennsylvanian underclays; groundwater, topographic, and tectonic controls, in Reinhardt, Jürgen, and Sigleo, W.R., eds., Paleosols and weathering through geologic time - principles and applications, Geological Society of America Special Paper 216, p. 81-101.

Houseknecht, D.W., 2001, Sequence stratigraphy and sedimentology of Beaufortian strata (Jurassic-Lower Cretaceous) in the National Petroleum Reserve-Alaska, in Houseknecht, D.W., ed., NPRA Core Workshop; Petroleum Plays and Systems in the National Petroleum Reserve-Alaska, SEPM (Society for Sedimentary Geology) Core Workshop 21, p. 57-88.

Houseknecht, D.W., and Bird, K.J., 2004, Sequence stratigraphy of the Kingak Shale (Jurassic-Lower Cretaceous), National Petroleum Reserve in Alaska: American Association of Petroleum Geologists Bulletin, v. 88, no. 3, p. 279-302.
Magoon, L.B., and Bird, K.J., 1988, Evaluation of petroleum source rocks in the National Petroleum Reserve in Alaska, using organic-carbon content, hydrocarbon content, visual kerogen, and vitrinite reflectance, in Gryc, George, ed., Geology and exploration of the National Petroleum Reserve in Alaska, 1974 to 1982: U.S. Geological Survey Professional Paper 1399, p. 381-450.

Magoon, L.B., Woodward, P.V., Banet, A.C., Jr., Griscom, S.B., and Daws, T.A., 1987, Thermal maturity, richness, and type of organic matter of source-rock units, in Bird, K.J., and Magoon, L.B., eds., Petroleum geology of the northern part of the Arctic National Wildlife Refuge, northeastern Alaska: U.S. Geological Survey Bulletin 1778, p. 127-180.

Masterson, W.D., and Paris, C.E, 1987, Depositional history and reservoir description of the Kuparuk River Formation, North Slope, Alaska, in Tailleur, I.L., and Weimer, Paul, eds., Alaskan North Slope Geology: Los Angeles, Society of Economic Paleontologists and Mineralogists, Pacific Section, p. 95-107.

Melvin, John, 1993, Evolving fluvial style in the Kekiktuk Formation (Mississippian), Endicott Field area, Alaska; base level response to contemporaneous tectonism: American Association of Petroleum Geologists Bulletin, v. 77, no. 10, p. 1723-1744.

Menning, Manfred, Weyer, Dieter, Drozdzewski, Günter, van Amerom, H.W.J., and Wendt, Imma, 2000, A Carboniferous time scale 2000; discussion and use of geological parameters as time indicators from Central and Western Europe: Geologisches Jahrbuch, ser. A, v. 156, p. 3-44.

Miall, A.D., 1974, Manganese spherulites at an intra-Cretaceous disconformity, Banks Island, Northwest Territories: Canadian Journal of Earth Science, v. 11, no. 12, p. 1704 1716 .

Mozley, P.S., 1989, Relation between depositional environment and the elemental composition of early diagenetic siderite: Geology, v. 17, no. 8, p. 704-706.

Mozley, P.S., and Carothers, W.W., 1992, Elemental and isotopic composition of siderite in the Kuparuk Formation, Alaska; effect of microbial activity and water/sediment interaction on early pore-water chemistry: Journal of Sedimentary Petrology, v. 62, no. 4, p. 681-692.

Mull, C.G., Tailleur, I.L., Mayfield, C.F., Ellersieck, Inyo, and Curtis, S.M., 1982, New upper Paleozoic and lower Mesozoic stratigraphic units, central and western Brooks Range: American Association of Petroleum Geologists Bulletin, v. 66 , no. 3, p. 348-362.

Nesbitt, H.W., and Young, G.M., 1982, Early Proterozoic climates and plate motions inferred from major element chemistry of lutites: Nature, v. 299, no. 5885, p. 715-717.

Nilsen, T.H., and Moore, T.E., 1984, The Kanayut Conglomerate in the westernmost Brooks Range, Alaska, in Coonrad, W.L., and Elliott, R.L., eds., The United States Geological Survey in Alaska; accomplishments during 1981: U.S. Geo- 
logical Survey Circular 868, p. 12-16.

Pracejus, Bernhard, and Bolton, B.R., 1992, Interdependence of $\mathrm{Mn}, \mathrm{Fe}$, and clay mineral formation on Groote Eylandt, Australia; a model for modern and ancient weathering environments: Catena Supplement 21, p. 371-397.

Retallack, G.J., 1997, A color guide to paleosols: New York, John Wiley \& Sons, 170 p.

Sigleo, W.R., and Reinhardt, Jürgen, 1988, Paleosols from some Cretaceous environments in the southeastern United States, in Reinhardt, Jürgen, and Sigleo, W.R., eds., Paleosols and weathering through geologic time; principles and applications: Geological Society of America Special Paper 216, p. 123-142.

Siok, J.P., 1985, Geologic history of the Siksikpuk Formation on the Endicott Mountains and Picnic Creek allochthons, north-central Brooks Range, Alaska: Fairbanks, University of Alaska, M.S. thesis, 253 p.

Slack, J.F., Dumoulin, J.A., Schmidt, J.M., Young, L.E., and Rombach, C.S., 2004, Paleozoic sedimentary rocks in the Red Dog Zn-Pb-Ag District and vicinity, western Brooks Range, Alaska; provenance, deposition, and metallogenic significance: Economic Geology, v. 99, no. 7, p. 1385-1414.

Waage, K.M., 1959, Stratigraphy of the Inyan Kara Group in the Black Hills: U.S. Geological Survey Bulletin 1081-B, p. 11-90.

White, T.S., Witzke, B.J., and Ludvigson, G.A., 2000, Evidence for an Albian Hudson Arm connection between the Cretaceous Western Interior Seaway of North America and the Labrador Sea: Geological Society of America Bulletin, v. 112, no. 9, p. 1342-1355.

White, T.S., Witzke, B.J., Ludvigson, G.A., and Brenner, R.L., 2005, Distinguishing base-level change and climate signals 